\title{
Materiales compuestos realizados a partir de nuevas tecnologías textiles
}

\section{Composite materials from new textile technologies}

Fecha de recepción: 7-III-97

Fecha de aceptación: 6-V-97
MIGUEL A. JÍMENEZ, LUIS CASTEJÓN, ANTONIO MIRAVETE ICMA - Dpto. de Ingeniería Mecánica. Universidad de Zaragoza

ESPAÑA

\section{SUMMARY}

The present paper describes in a general way the most important of the advanced textile technologies which are oriented to the manufacturing of organic matrix composite materials, the paper presents their applications and the possibilities of future development. The use of these advanced weaving techniques allows the production of near-net-shaped preforms, which results in important savings in processing costs; moreover, these textile processes offer the possibility of introducing out-of-plane reinforcing fibres, so there is an important increment of the impact strength and the damage tolerance of the final material.

\section{INTRODUCCIÓN}

En los últimos años ha crecido en todo el mundo el interés en la utilización de tecnologías textiles avanzadas en el proceso de fabricación de materiales compuestos de matriz orgánica. El uso de estas tecnologías textiles avanzadas, tales como el braiding, $3 D$-weaving, weft-knitting, warp-knitting y el cosido, permite obtener preformas de distintos tipos de fibras continuas como vidrio, carbono $o$ aramida. Estas preformas son cercanas a la forma final de la pieza, y en ellas la orientación de la fibra no está restringida a un plano. La producción de estas preformas es un proceso altamente automatizado que se completa con la impregnación de la preforma mediante inyección de

\section{INTRODUCTION}

In the last years, the interest in the use of advanced textile technologies in the processing of composite materials of organic matrix has increased all over the world. The utilisation of these advanced textile technologies, such as braiding, 3D-weaving, weftknitting, warp-knitting and stitching, allows to obtain preforms of several types of continuous fibres such as glass, carbon or aramid. These preforms are close to the final shape of the part, and in them, the fibre orientation is not restrained to a plane. The production of these preforms is a highly automated process which is completed with the impregnation of the preform through resin injection. This technology makes possible 
resina. Esta tecnología permite la fabricación de componentes estructurales de formas complejas con un precio relativamente bajo. Además, la posibilidad de disposición tridimensional de las fibras, evita los problemas de delaminación y aumenta de forma significativa la resistencia frẹnte a impacto del material.

\section{PREFORMAS TEXTILES AVANZADAS FRENTE A LA PROBLEMÁTICA HABITUAL DE LOS MATERIALES COMPUESTOS DE MATRIZ ORGÁNICA}

Las propiedades mecánicas de un material compuesto de matriz orgánica vienen dictadas por el tipo de fibra utilizada como refuerzo. La aplicación estructural de estos materiales se ve limitada de forma fundamental a aquellos reforzados con fibra continua, donde una orientación de las fibras en función de las cargas a las que va a verse sometido el material, permite obtener importantísimos ahorros de peso frente a la utilización de materiales convencionales como el acero.

La anisotropía de estos materiales se emplea de forma óptima mediante la utilización de laminados de material unidireccional. Estos laminados se fabrican mediante el apilamiento, según distintos ángulos determinados por las cargas y requerimientos, de varias laminas de refuerzo unidireccional. La utilización de tejidos planos, constituidos por fibras continuas entrelazadas de forma bidimensional, reduce los costes de fabricación respecto a aquellos que corresponden a los laminados de material unidireccional, permitiendo obtener propiedades mecánicas que, aunque inferiores, siguen resultando interesantes en muchas aplicaciones. En cualquier caso, las propiedades mecánicas de estos materiales fuera del plano son mucho menores que las que presentan en el plano al no existir refuerzo en esta dirección; esto se traduce en bajas propiedades a través del espesor de material, con problemas de delaminación y de tolerancia al daño frente a cargas de impacto.

Junto a los citados problemas de tolerancia al daño, es el alto precio de fabricación, la causa fundamental que limita el uso extensivo de los materiales compuestos de matriz orgánica. El precio elevado es fruto de la presencia habitual de labores manuales en el proceso de fabricación y de los costosos medios de inspección que se requieren para asegurar la calidad de la estructura. Aunque los últimos años han sido testigos de la utilización de estos materiales en aplicaciones no sólo aeronáuticas, sino también dentro de otras industrias de transporte y en la ingeniería civil, su uso se ve muchas veces limitado a aplicaciones en las que el aumento de precio queda justificado por substanciales mejoras en el comportamiento estructural the manufacturing of structural components of complex shapes at a relatively low price. Moreover, the possibility of three-dimensionally arranging the fibres avoids delamination problems and significantly increases the impact strength of the material.

\section{ADVANCED TEXTILE PREFORMS IN RELATION TO THE USUAL PROBLEMS OF ORGANIC MATRIX COMPOSITE MATERIALS}

The mechanical properties of a composite material mainly depend on the sort of fibre which is used as reinforcement. The structural use of these materials is mainly limited to those which are reinforced with continuous fibres; the correct orientation of the fibres, in relation to the loads to which the material will be subjected, allows to obtain very important weight savings with regard to the use of conventional materials as steel.

The anisotropy of these materials is employed in an optimum way by using laminates of unidirectional material. These laminates are manufactured by stacking several layers of unidirectional reinforcement at different angles which are determined by loads and requirements. The use of plane weaves, consisting of continuous fibres which are two-dimensionally interlocked, reduces the manufacturing costs in relation to those that correspond to the laminates of unidirectional material, and allows to obtain mechanical properties that even thought being lower are interesting in many applications. Anyway, the out-of-plane properties of these laminates, using unidirectional laminae or plain weaves, are much lower than those which are present in the plane because there is not reinforcement in that direction; this results in low properties through the material thickness, with problems of delamination and damage tolerance under impact loads.

Besides the mentioned problems of damage tolerance, it is the high price of manufacturing the main reason which limits the extensive use of the organic matrix composite materials. The high price is due to the usual presence of hand labours during the manufacturing processes and to the expensive inspection methods which are required (1) ensure the quality of the structure. Although the last years have seen how these materials have expanded their application fields from aeronautic engineering to other types of transportation and to the civil engineering, their utilisation is many times restrained to applications in which the increasing of price is justified by outstanding improvements in the structural behaviour. 


\section{BRADING}

El braiding consiste en un proceso de trenzado de múltiples hebras procedentes de bobinas con desplazamiento controlado numéricamente; las hebras se entrelazan formando ángulos que varían entre $10^{\circ} \mathrm{y}$ $80^{\circ}$, pudiéndose incluir también fibras a $0^{\circ}$. La Figura 1 muestra un esquema de la distribución de las hebras de fibra.

\section{BRAIDING}

The braiding process consists of braiding multiple yarns from spools with numerically controlled displacement; the varns are interlocked forming different angles ranging from $10^{\circ}$ to $80^{\circ}$, being also possible to include fibres at $0^{\circ}$. The Figure 1 shows an sketching of the fibre yarns distribution.

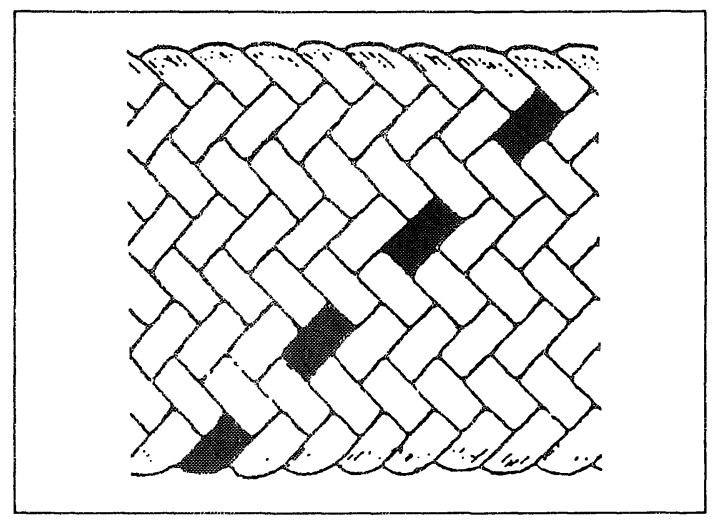

Fig. 1.- Esquema de un tejido tipo braiding

Fig. 1.- Sketch of a braided weave.

Existen dos tipos de braiding, el 2D-braiding y el $3 D$-braiding. Mediante el 2D-braiding se obtienen estructuras de tipo tubular al trenzar las hebras sobre un mandril correspondiente a la sección que se desea obtener. El 3D-braiding a diferencia del bidimensional, incorpora fibras en direcciones perpendiculares a la sección de trenzado, siendo especialmente adecuado para la fabricación de perfiles con secciones tipo C, T, I, etc.; el control numérico de cada una de las bobinas permite gran flexibilidad en los ángulos de orientación de las fibras, con lo que se puede disponer el refuerzo en función de los requerimientos a los que vaya a estar sometido el perfil. A las excelentes propiedades mecánicas a través del espesor obtenidas en estos perfiles, se une una elevada capacidad de absorción de energía bajo cargas de aplastamiento axial progresivo.

El desarrollo del braiding se centra fundamentalmente en las fibras de carbono debido a que su trenzado no presenta las complicaciones que aparecen para su utilización en otras tecnologías textiles. El comportamiento elástico del material final es semejante al que se obtendría con un refuerzo convencional con porcentajes de fibra y orientaciones equivalentes, mientras que los valores de resistencia en el plano disminuyen en torno a un $20 \%$ como consecuencia del daño que sufren las fibras de carbono al ser trenzadas. Los elementos estructurales
There are two types of braiding, the $2 D$-braiding and the 3D-braiding. By means of the 2D-braiding, tubular shaped structures are obtained by braiding the fibre yarns on a mandrel which corresponds to the desired section. The 3D-braiding unlike the two-dimensional one, has fibres in the perpendicular directions to the braiding section, this is specially suitable for manufacturing profiles with different types of section: $C, T, I$, etc.; the numerical control of each one of the spools allow big flexibility in the orientation angles of the fibres so having the possibility of arranging the reinforcement as function of the requirements that the profile will have to withstand. As well as the excellent mechanical properties through the thickness which are obtained in these profiles, they also exhibit a high capacity of energy absorption under loads of progressive axial crushing.

The braiding development mainly focuses in the carbon fibres due to the fact that braiding them has not the problems that appear with the carbon fibres in other textile technologies. The elastic behaviour of the final material is similar to that which would be obtained with a conventional reinforcement with equivalent fibre percentage and orientations, while the in-plane strength values diminish around $20 \%$ as a consequence of the damage that the carbon fibres suffer whilst they are being braided. The structural elements which are carried out from carbon braiding reinforcements are 
realizados a partir de braiding en carbono son principalmente perfiles de secciones abiertas o cerradas, pudiéndose realizar secciones muy complejas. Estos elementos estructurales pueden utilizarse como perfiles rigidizadores en paneles.

\section{3D-WEAVING}

Cuando se habla de tejidos como refuerzo en un material compuesto, se está hablando generalmente de tejidos que se son básicamente bidimensionales y bidireccionales, siendo estas dos direcciones la de urdimbre y la de trama. Como ya se ha citado anteriormente, los laminados formados por el apilamiento de estos tejidos presentan deficiencias en cuanto a las propiedades fuera del plano. Este problema puede solucionarse mediante la tecnología del $3 D$-weaving, consistente en tejer de forma conjunta varios tejidos bidimensionales, añadiendo a las fibras de urdimbre y trama de esos tejidos $2 \mathrm{D}$ nuevas fibras de urdimbre que liguen las distintas laminas entre si. La Figura 2 muestra el esquema de la sección de uno de estos tejidos.

Las propiedades fuera del plano de este tipo de tejidos son muy superiores a las correspondientes a un laminado equivalente de tejidos convencionales Además, se superan los problemas de delaminación que aparecen en los laminados convencionales.

Actualmente existe gran interés en mejorar esta tecnología para lograr incorporar, además del refuerzo fuera del plano, fibras orientadas según distintos ángulos con las direcciones de urdimbre y trama. El objetivo es mejorar el comportamiento frente a esfuerzos cortantes en el plano, dado que el comportamiento frente a este tipo de esfuerzos no es óptimo cuando sólo se dispone de fibras en las direcciones de urdimbre y trama. mainly profles with open or closed sections, being possible to get very complex sections. These structural elements can be used as stiffeners in panels.

\section{3D-WEAVING}

The use of the term "weave" related to a reinforcement in a composite material, usually makes reference to weaves which are basically two-dimensional and twodirectional, being these two directions warp and weft. As it has been previously mentioned, the laminates which are constituted by the stacking of these weaves present shortcomings related to their out-of-plane properties. This problem can be overcome with the 31)weaving technology, which consists of simultaneously weaving several two-dimensional weaves, at the time that new warp yarns that connect these $2 D$ weaves are added to the usual warp and wefl fibres. The Figure 2 shows the sketching of the section of cne of these weaves.

The out-of-plane properties of this type of weaves are much higher than those that correspond to an equivalent laminate of conventional weaves. Moreover, the problems of delamination that appear in the conventional laminates are overcome.

Nowadays it exists a big interest on improving this technology to get the introduction, in addition to the out-of-plane reinforcement, of in-plane fibres at different angles to the warp and weft directions. The objective is to improve the behaviour under in-plane shear loads because the behaviour under this sort of load is not the optimum when there are only fibres in the warp and weft directions.

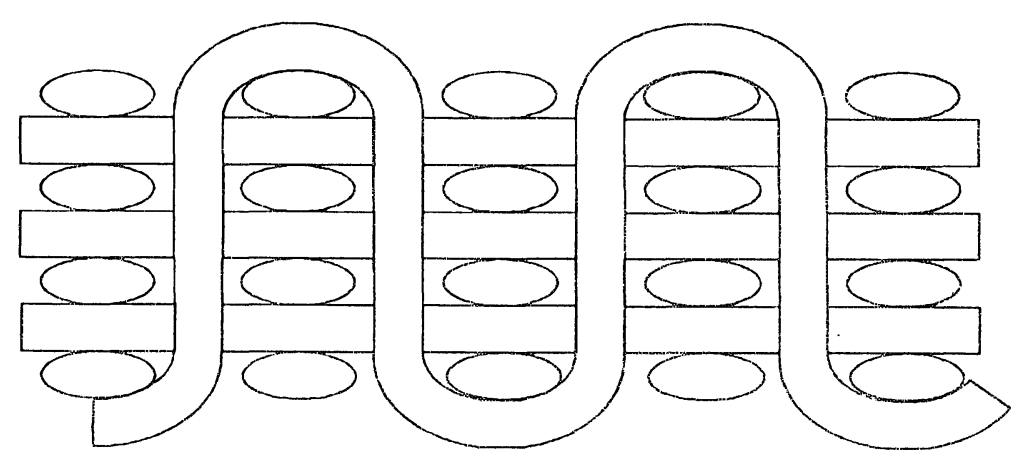

Fig. 2.- Sección de un tejido tipo 3D-weaving.

Fig. 2.- Section of a weave of the 3D-weaving type. 
La deformabilidad de las preformas realizadas a partir de esta tecnología textil es reducida, por lo que suelen destinarse a paneles planos o de pequeña curvatura; por contra, permiten alcanzar propiedades mecánicas muy importantes, especialmente fuera del plano.

\section{WEFT-KNITTING}

Los tejidos de weft-knitting se realizan a partir de una única hebra que va formando sucesivas curvas con los movimientos de las agujas, realizándose el tejido en la dirección transversal. Se puede hablar de que el tejido se realiza fila a fila, como puede apreciarse en la Figura 3. Las diferentes agujas pueden controlarse de forma independiente, consiguiéndose multitud de variaciones en la arquitectura del tejido.

La disposición de las fibras en múltiples curvas confiere al tejido una elevada capacidad de deformación, permitiendo la elaboración de preformas complejas con dobles curvaturas. Al mismo tiempo, esta disposición de las fibras en forma de curvas reduce las propiedades mecánicas finales del tejido; esta reducción obedece no sólo a motivos geométricos sino también al daño que sufren las fibras al ser curvadas; este problema es especialmente importante en el caso de las fibras de carbono. Así pues, las propiedades obtenidas en materiales compuestos reforzados con tejedurías de este tipo son, en el plano, inferiores a las obtenidas con los mismos porcentajes de fibra al utilizar tejidos planos convencionales; sin embargo, los valores de resistencia a impacto aumentan notablemente.

Los desarrollos actuales de esta tejedurías se centran en la incorporación al tejido de fibras rectas en distintas direcciones para mejorar las propiedades mecánicas. La Figura 4 ilustra de forma esquemática la incorporación de fibras adicionales en la dirección longitudinal.

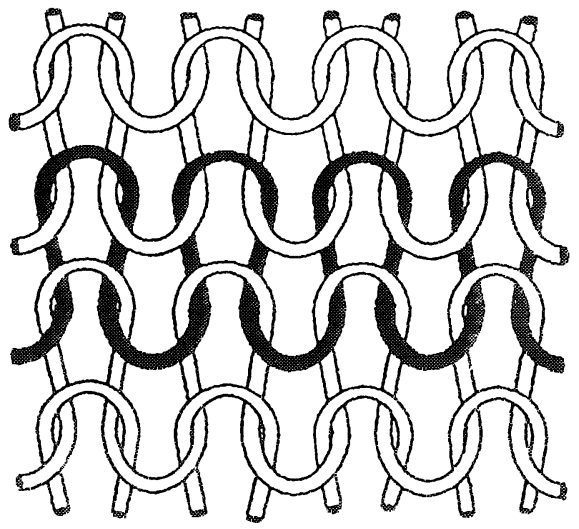

Fig. 3.- Esquema de un tejido de tipo weit-knitting.

Fig. 3.- Sketch of a weft-knitting weave.
The shapeability of the preforms which are realised by this textile technology is reduced and so they are used for flat panels or for panels with limited curvature; on the other hand, this technology allows to get very high mechanical properties specially through the thickness.

\section{WEFT-KNITTING}

The weft-knitting fabrics are realised from a single yarn which forms successive loops following the needles movements; the weave is carried out in the transverse direction. It can be said that the weave is carried out row by row as it can be appreciated in Figure 3. The different needles can be independently controlled, getting multitude of variations in the weaving architecture.

The arrangement of the fibres in multiple loops gives to the weave a high shapeability, allowing the manufacturing of complex preforms with double curvature. At the same time, this fibre arrangement in multiple loops reduces the final mechanical properties of the weave; this reduction obeys not only to geometric reasons but also to the damage that the fibres suffer whilst they are being woven, specially when weaving carbon fibres. Hence, the final properties of the composite material with this kind of weaves as reinforcement are, in the plane; lower that those that would be obtained with the same fibre percentage in a conventional plane weave; however, the impact strength values remarkably increase.

The present developments in these weaving techniques are focused on including in the weave straight fibres along different directions to increase the mechanical properties. The Figure 4 shows an sketching of the inclusion of additional fibres in the longitudinal direction.

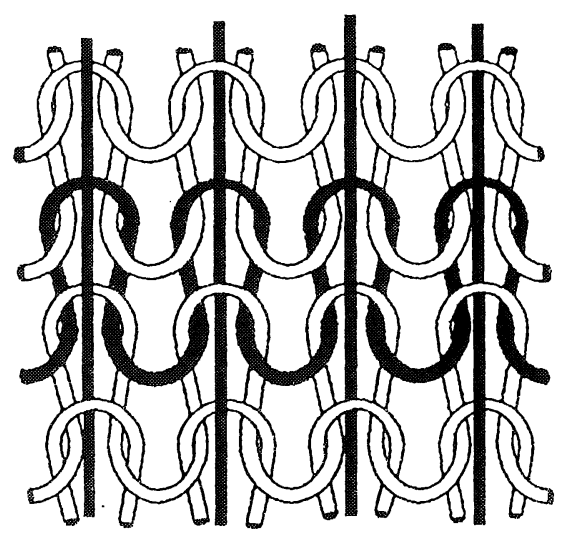

Fig. 4.- Tejido tipo weft-knitting al que se han añadido fibras rectas cn la dirección longitudinal.

Fig. 4.- Sketch of a weft-knitting weave with added longitudinal straight fibres. 
Las preformas de weft-knitting están generalmente destinadas a la elaboración de paneles con dobles curvaturas y requerimientos mecánicos reducidos.

\section{WARPBNTTING}

En el warp-knitting, a diferencia del weft-knitting, son varias hebras las que se incorporan al tejido. Cada una de esas hebras describe las mismas curvas, realizándose el tejido en dirección longitudinal. La Figura 5 muestra un esquema de esta tecnología textil. El proceso de tejeduría es muy rápido, pero la maquinaria es más cara que en el caso del weft-knitting, donde se utilizaba una hebra, mientras que ahora hay que alimentar la máquina con cientos de ellas.

La tecnología para añadir fibras rectas en distintas direcciones está más desarrollada que en el caso del weft-knitting, lo que permite obtener mejores propiedades mecánicas en el plano

El warp-knitting se destina a la elaboración de paneles planos o curvados y en los que se necesitan propiedades superiores a las que alcanzan con el weft-knitting. Las posibilidades de curvatura y deformabilidad de las preformas son, en general, inferiores a las que permite el weft-knitting.

Existe también la posibilidad de realizar tejidos tridimensionales. En este caso se realizan de forma simultánea dos tejidos tipo warp-knitting bidimensionales al tiempo que se introducen fibras que conectan estos dos tejidos. Estos tejidos se destinan a la elaboración de estructuras tipo sandwich.

La elevada flexibilidad en la disposición y entrelazado de fibras en el proceso de warp-knitting permite obtener preformas con estructura global de malla, lo que abre su aplicación a elementos estructurales en los que se requiera ventilación.
The weft-knitting preforms are usually intended to the manufacturing of double curved panels with low mechanical requirements.

\section{WARP-KNITTING}

In the warp-knitting unlike the weft-knitting case, several yarns are incorporated to the weave. Each one of these yarns makes the same loops, and the weave is carried out in the longitudinal direction. The Figure 5 shows an sketch of this textile technology. The weaving process is very fast, but the machinery is more expensive than in the case of weft-knitting where only one yarn is needed while now the machine requires hundreds of them.

The technology of adding straight fibres in different directions is more developed than in the case of weftknitting, this allows to obtain better in-plane mechanical properties.

The warp-knitting is intended to the manufacturing of flat or curved panels in which higher properties than those which can be obtained with the weft-knitting are needed. The possibilities of curvature and shapeability of the preforms are generally lower than those that the wefí-knitting allows:

It exists also the possibility of carrying out threedimensional weaves. In this case two conventional twodimensional warp-knitting weaves are simultaneously carried out at the time that fibres interlocking these two weaves are introduced. These weaves are used in the manufacturing of sandwich structures.

The high flexibility in the arranging and interlocking of the fibres in the warp-knitting process allows to obtain preforms with a meshed global structure, this opens its application field to structural elements in which ventilation is required.

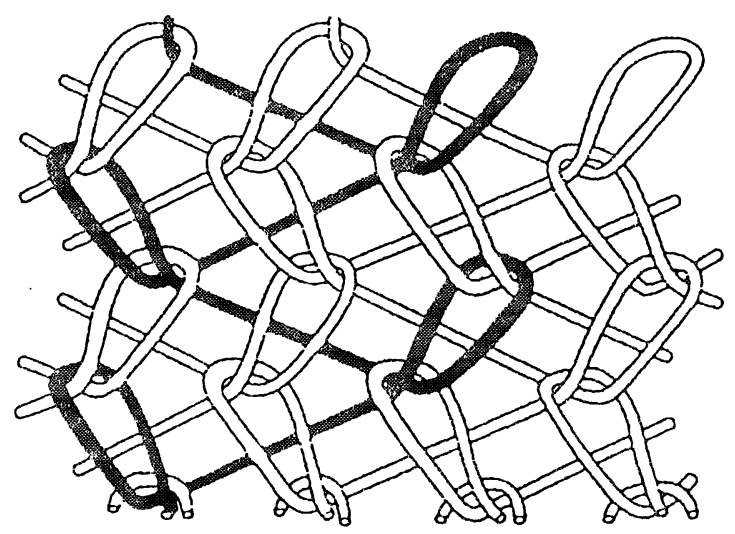

Fig. 5.- Fisquema de un tejido de tipo warp-knitting.

Fig. 5. - Sketch of a warp-knitting wean'e. 


\section{COSIDO}

$\mathrm{El}$ interés que las distintas técnicas de cosido tienen para la industria de los materiales compuestos obedece a dos razones principalmente. Por un lado, existen técnicas de cosido que posibilitan la unión de múltiples láminas de refuerzo (unidireccionales o tejidos), mejorándose substancialmente, como ocurría en el caso del $3 D$-weaving, el comportamiento frente a esfuerzos de cortadura interlaminar e incluso la resistencia y tolerancia a impacto; la Figura 6 muestra este tipo de utilización. La segunda razón, es la posibilidad de unir diferentes preformas con anterioridad a depositarlas en el molde y proceder a la inyección de resina; de este modo, se reducen los costes de fabricación al reducirse el número de componentes finales a ensamblar. Además estas uniones mediante cosido son muy resistente frente a cargas de pelado y cargas a través del espesor. La Figura 7 representa la utilización del cosido para la combinación de preformas.

A las dificultades técnicas de los procesos de cosido se une otro problema, la reducción de las propiedades

\section{STITCHING}

The interest that the different stitching techniques have for the composite materials industry is mainly due to two reasons. The first reason is that there are stitching techniques that make possible the joining of multiple laminae of reinforcement (unidirectional or weaves) so substantially improving, as in the case of 3D-weaving, the behaviour under interlaminar shearing loads and even the impact strength and damage tolerance; the Figure 6 shows this kind of stitching. The second reason is the possibility of joining different preforms prior to put them in a mould and injecting the resin; this way, the manufacturing costs are reduced due to the reduction of the number of final components to assemble, also these stitched joints are very resistant under peeling loads and loads though the thickness. The Figure 7 sketches the use of the stitching technique for combining preforms.

In the stitching process, the reduction of the in-plane mechanical properties of the stitched preforms is added

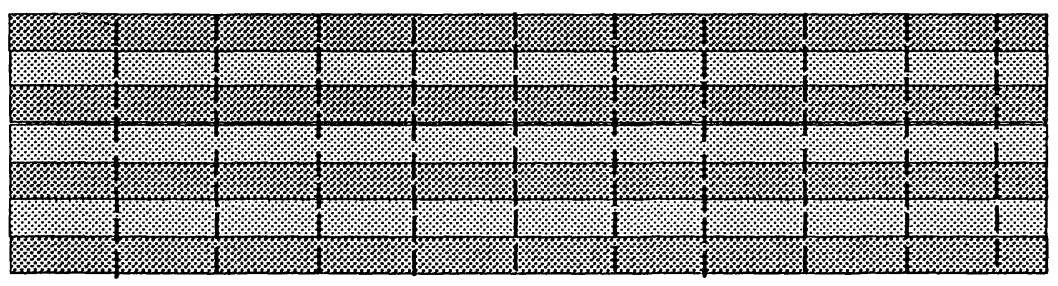

Fig. 6.- Uso del cosido para la combinación de varias láminas de refuerzo.

Fig. 6.- Using of stitching to combine several reinforcing layers.

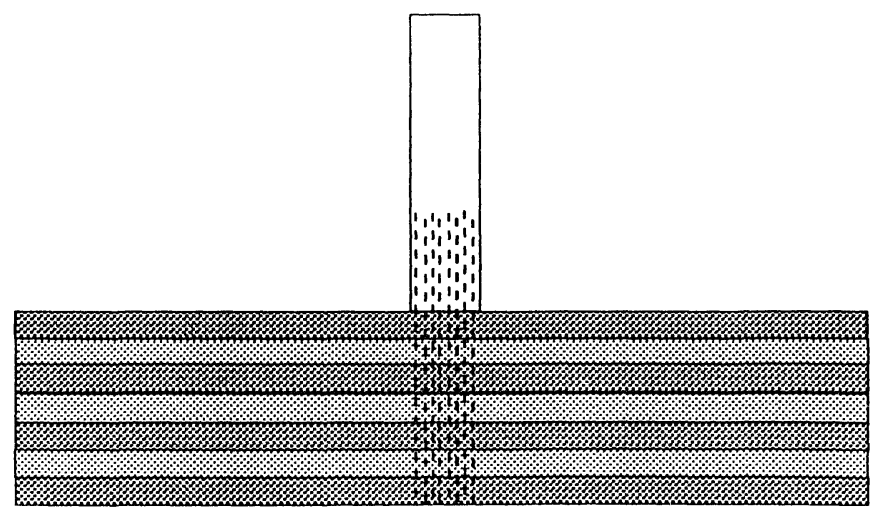

Fig. 7.- Uso del cosido para la combinación de proformas.

Fig. 7.- Use of stitching to combine preforms. 
mecánicas. Esta reducción obedece a varios factores, como son ligeros desplazamientos y curvaturas de las fibras de las preformas cosidas en torno a las fibras del cosido, daño en estas mismas fibras, ocasionado por las agujas utilizadas en el cosido, y agrietamiento en la matriz en zonas ricas en resina.

\section{FABRICACIÓN DEL MATERIAL FINAL A PARTIR DE LAS PREFORMAS TEXTILES}

E1 RTM, moldeo por transferencia de resina, es la técnica de fabricación más utilizada con las tecnologías textiles presentadas en este artículo. El RTM consiste, básicamente, en la inyección de la resina en un molde cerrado en el que se han depositado con anterioridad las fibras de refuerzo. El RTM es uno de los procesos de fabricación de materiales compuestos reforzados con fibras continuas de mayor productividad, productividad que se ve aumentada al utilizar como refuerzo preformas textiles.

El aumento de productividad de los proceso de RTM cuando se utilizan preformas textiles obedece a dos motivos. En primer lugar, se simplifican notablemente los procesos de colocación de las fibras de refuerzo en el molde según las orientaciones espesores requeridos. En segundo lugar, la utilización de preformas complejas cercanas a la forma final, y la integración de subpreformas mediante técnicas de cosido, permiten la obtención, de forma integral, de piezas y componentes de material compuesto; piezas y componentes que, con otro tipo de refuerzo, consistirían en distintos subcomponentes de material compuesto, unidos mecánicamente o mediante adhesivo.

El problema de la utilización del RTM con las preformas textiles reside en la dificultad de lograr que la resina de distribuya de forma uniforme entre la complicada arquitectura del tejido. En la actualidad, gran parte del trabajo realizado para mejorar este aspecto se centra en el desarrollo de sistemas de resina adecuados para lograr la impregnación correcta de toda la preforma.

Además de la fabricación por RTM, existen otros procesos de fabricación que se pueden utilizar a partir de las preformas textiles. En concreto, las preformas obtenidas mediante braiding pueden ser transformadas en el correspondiente perfil de material compuesto mediante pultrusión, mientras que los tejidos realizados mediante $3 /$ )-weaving o knitting pueden transformarse en paneles de material compuesto mediante distintos procesos de prensado. to the technical problems of the process. This reduction obeys to several reasons as slight displacements and curvatures of the fibres of the stitched preforms around the stitching fibres, damage in these same fibres which is produced by the needles, and cracking in the matrix in the areas which are rich in resin.

\section{MANUFACTURING OF THE FINAL MATERIAL FROM THE TEXTILE PREFORMS}

The RTM, resin transfer moulding, is the manufacturing technique usually employed with the textile technologies which have been presented in the paper. The RTM basically consists of injecting the resin in a closed mould in which previously the reinforcing fibres have been placed. The RTM is one of the manufacturing processes for composite materials with higher productivity, this productivity is increased if textile preforms are used as reinforcement.

The increasing of productivity of the RTM process when textile preforms are used obeys to two reasons. First, the arranging process of the fibres in the mould. with the necessary thickness and orientations, is remarkably simplified. The second reason is that the use of near-net-shape preforms and the integration of subpreforms by stitching techniques allow to obtain in an integral way parts and components of composite material; these parts and components, if using other kind of reinforcement, would consist of different subcomponents joined by adhesive or mechanical joints:

The problem of using RTM with textile preforms is the difficulty of getting a uniform distribution of the resin through the complex weave architecture. Nowadays. many of the efforts which are realised to improve this aspect, are focused on the development of the adequate resin systems to the correct impregnation of the whole preform.

Apart from the manufacturing by RTM, there are other manufacturing processes that can be used from textile preforms. To sum up, the braided preforms can be transform in the correspondent profile of composite material through pultrusion; also, the weaves which are carried out by 3D-weaving, or knitting can be transformed into composite material panels by different pressing processes: 


\section{CONCLUSIONES}

La fabricación de preformas mediante las tecnologías textiles de braiding, 3D-weaving, weft-knitting, warpknitting y cosido, permite sustituir el tradicional trabajo manual en los procesos de elaboración de laminados, por procesos altamente automatizados, obteniéndose el correspondiente ahorro en tiempos de fabricación y costes. Además, la posibilidad existente en muchos casos de introducir fibras de refuerzo fuera del piano permite aumentar de forma drástica propiedades como la tolerancia al daño, reduciéndose los costes de mantenimiento y control de calidad.

\section{CONCLUSIONS}

The manufacturing of preforms using the techniques of braiding, 3D-weaving, weft-knitting, warp-knitting and stitching, allows to substitute the traditional hand labour of the lamination processes by highly automated processes; thus, the correspondent saving is obtained in terms of manufacturing time and costs. Also, the possibility that exists in many cases of introducing outof-plane reinforcing fibres allows to increase drastically some properties as the damage tolerance; so, the costs of maintenance and quality control decrease.

\section{BIBLIOGRAFIA}

(1) ANTEQUERA P., JMÉNEZ L., MIRAVETE A.: "Los materiales compuestos de fibra de vidrio". Secretariado de Publicaciones de la Universidad de Zaragoza, Zaragoza, 1991.

(2) F. K. Ko.: "Global activities in advanced textile preforming". Proceedings of the III TEXCOMP. Aachen, diciembre 1996.

(3) D. PHILIPS, I. VERPOEST: “3D-Knitted Fabrics for Sandwich Panels”. SAMPE Journal, Vol.32, No. 6, noviembre/diciembre 1996.

(4) G. RÖSSLER, A. KLEIST, M. SCHNEIDER, TH. BISCHOFF: “Textile reinforcements - fit for use in civil engineering”. Proceedings of the III TEXCOMP. Aachen, diciembre 1996.

(5) J. BRAND, K. DRECHSLER.: 'New'Textile technologies". Proceedings of the I International Workshop on Automotive Engineering. Zaragoza, marzo 1997.

\section{publicación del IETCC/CSIC}

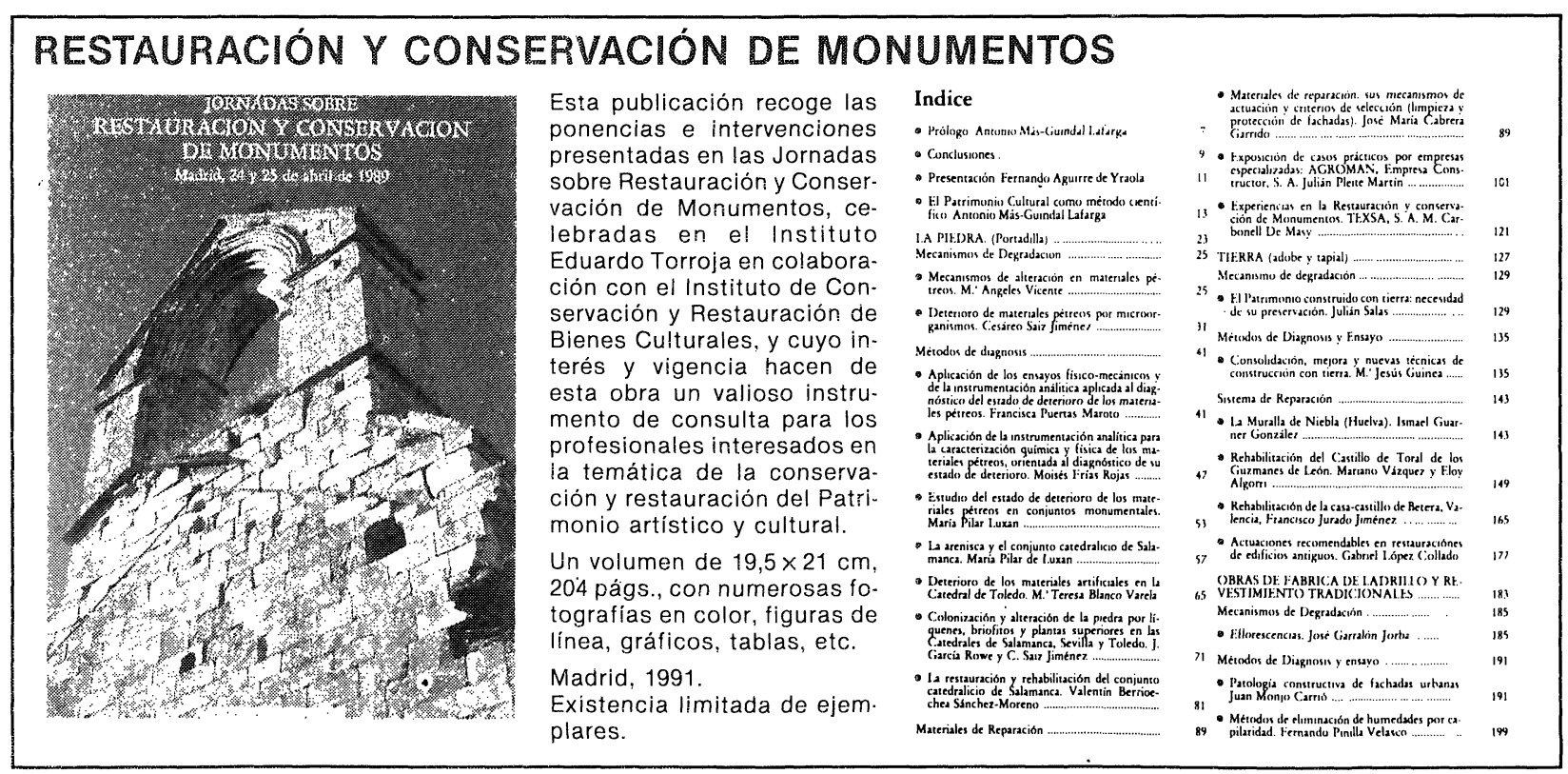

